\title{
Responses of Metabolic Hormones to Prolonged Intraduodenal Infusion of Amino Acids in Sheep
}

\author{
Tetsuya Kunara*, Kazuo Katoh, Shinichi Oda, \\ Akira OHNEDA** and Yasuyuki SASAKI \\ Department of Animal Physiology, Faculty of \\ Agriculture, and **Health Centre, Tohoku \\ University, Aoba-ku, Sendai-shi 981
}

(Received March 9, 1992)

\begin{abstract}
Glycine (Gly), L-leucine (Leu) or L-aspartic acid (Asp) were continuously infused into the duodenum of six castrated male sheep fitted with a chronically indwelling catheter in the duodenum to investigate the effects of these amino acids on GH, IGF-I, insulin and glucagon responses. Amino acids were infused at doses of 3.6, 7.2 and $14.4 \mathrm{mmol} / \mathrm{kg} /$ day for $96 \mathrm{~h}$. The effects on plasma concentrations of glucagon, insulin, growth hormone $(\mathrm{GH})$ and insulin-like growth factor-I (IGF-I) were studied during the last $24 \mathrm{~h}$ of infusion. Gly administration brought about a significant and dose-related increase in plasma glucagon and insulin concentrations, the molar ratio of insulin to glucagon ( $\mathrm{I} / \mathrm{G}$ ratio) being significantly reduced. Leu and Asp administration significantly increased the concentrations of insulin, glucagon and IGF-I. However, none of the amino acids used caused a significant increase in the GH concentration at these infusion rates. The present results suggest that it would be possible to modify plasma concentrations of glucagon, insulin and IGF-I by intraduodenal infusion of Leu and Asp, and that Gly might be used to reduce the $\mathrm{I} / \mathrm{G}$ ratio in sheep.
\end{abstract}

Anim. Sci. Technol. (Jpn.) 63 (11) : 1123-1133, 1992

Key words : amino acids, hormone responses, sheep

It has been proposed that hormones such as glucagon, insulin and growth hormone (GH) are important regulators of the partition and utilization of energy-yielding substrates and nutrients, thereby influencing animal performance and production. Glucagon is known to stimulate both glycogenolysis and gluconeogenesis, resulting in glucose release from the liver ${ }^{3)}$ and an increased supply of glucose that is required for milk synthesis in lactating animals ${ }^{2)}$. Insulin is one of the most important factors enhancing protein synthesis ${ }^{12)}$ and glu- cose uptake by peripheral tissues. GH possesses both galactopoietic and growth promoting actions, which are partially mediated by insulin-like growth factor-I (IGF-I) : its physiological significance has been reviewed with particular emphasis to animal production ${ }^{11}$.

Intravenous arginine (Arg) administration, the most widely used amino acid infusion, elevated the plasma concentrations of $\mathrm{GH}$ and prolactin and increased milk yield in dairy cows ${ }^{4}$. Administration of amino acids and proteins into the small intestine has also been

* Present address : Biochemical Research Laboratory, Morinaga Milk Industry Co. Ltd., Zamashi 228

Anim. Sci. Technol. (Jpn.) 63 (11) : 1123-1133 1123 
reported to improve milk production in cows ${ }^{5)}$. From these results, it has been proposed that changes in the hormonal status induced by amino acid adiministration might be one of several strategies that could be adopted to improve animal production ${ }^{25}$.

In our previous report ${ }^{17)}$ in which seventeen amino acids were intravenously administered to sheep, we found that each amino acid exerted a different stimulating effect on the arterial concentrations of $\mathrm{GH}$, glucagon and insulin. Among these amino acids, glycine (Gly), alanine and serine were most effective in increasing the concentration of glucagon, while L-leucine (Leu) was the most potent stimulator for insulin. On the other hand, L-aspartic acid (Asp) was the most effective amino acid in stimulating $\mathrm{GH}$ secretion. Arg was only a moderate secretagogue for the secretion of these hormones.

The aim of present experiment, on the basis of our previous findings, was to investigate the effects of continuous infusions of Gly, Leu and Asp into the duodenum for 4 days on the plasma concentrations of $\mathrm{GH}$, glucagon, insulin and IGF-I in sheep. It was shown that intraduodenal administration on these amino acids modified the plasma levels of these hormones responsible for nutrient metabolism.

\section{Materials and Methods}

Animal : Six cross-bred castrated male sheep aged 5-7 years and weighing $48^{-} 53 \mathrm{~kg}$ were used. They were housed in metabolic cages and offered lucerne (Medicago sativa) hay cubes (46.4 (DM) g/ kg body-weight ${ }^{0.75}$ ) once daily at $17: 00$ hours. Feed was withdrawn at $18: 30$ hours and uneaten food was weighed. Water was available continuously.

Animals had their left commom carotid artery surgically placed in a loop of skin. A chronic indwelling catheter was placed in the duodenum at least 3 weeks before the experiment began, approximately $10 \mathrm{~cm}$ distal to the pylorus. The catheter extended $3 \mathrm{~cm}$ into the duodenum in a distal direction. Animals were anesthetised with sodium pentobarbitone (25 $\mathrm{mg} / \mathrm{kg}$ ) for both surgical procedures. Catheters were flushed and filled with distilled sterile water. During the post-operative recovery period, animals were trained to become accustomed to the experimental procedure and surroundings.

Experimental procedure: Gly and Asp were dissolved in warm distilled sterile water and the solution was adjusted to $\mathrm{pH} 7.0$ with sodium hydroxide before use. Because of the low solubility of Leu at $\mathrm{pH} 7.0$, the Leu solution was adjusted to $\mathrm{pH} 2.5$ with hydrochloric acid, at the same concentration as the other solutions.

Gly, Asp or Leu (Wako Pure Chemical Industries, Osaka, Japan) were infused into the duodenum through the catheter for $96 \mathrm{~h}$ at 9 -days intervals and each infusion began at 12 : 00 hours.

The infusion rates for each amino acid were 0 (saline), 3.6, 7.2 and $14.4 \mathrm{mmol} / \mathrm{kg} /$ day with the exception of Leu which was not infused at the highest rate, because of the low solubility of Leu at the highest dose. The infusion volume was constant $(1 \mathrm{ml} / \mathrm{min})$, while the order of amino acid administration and the infusion rate used were randomized.

Blood sampling was carried out during the last $24 \mathrm{~h}$ of the infusion at $2-\mathrm{h}$ intervals from the exteriorized carotid artery through a catheter. The indwelling catheter was inserted by puncturing the artery at least $1 \mathrm{~h}$ before blood sampling, and was filled with $3.8 \%$ trisodium citrate solution.

Arterial blood collected into heparinized syringes was immediately transferred into polyethylene test tubes cooled in ice water and centrifuged at $4^{\circ} \mathrm{C}$. Each tube contained 0.05 mmol of benzamidine per $\mathrm{m} l$ of blood. A portion of plasma was deproteinized with trichloroacetic acid ( $0.3 \mathrm{M})$ and the supernatant was stored at $-20^{\circ} \mathrm{C}$ until used for glucose determination by the glucose oxidase method ${ }^{14)}$ 
and $\alpha$-amino nitrogen estimation by the method of LEE and TAKAHASHI ${ }^{19)}$. A further aliquot of plasma was stored at $-20^{\circ} \mathrm{C}$ for glucagon, insulin, GH and IGF-I assays. Plasma glucagon was assayed ${ }^{22)}$ using dextran-coated charcoal and antiserum G-42 $\mathrm{E}$ which was highly specific for the C-terminal portion of glucagon ${ }^{23)}$. The assay revealed a minimal detectable concentration of $8 \mathrm{pg} / \mathrm{ml}$. Plasma insulin was assayed by the method of SASAKI and TAKAHASHI ${ }^{27)}$. A highly purified bovine $\mathrm{GH}$ used for iodination and as standard was prepared from bovine pituitaries by the method of SPITSBERG ${ }^{32)}$ in this laboratory as described previously ${ }^{17)}$. Plasma $\mathrm{GH}$ was assayed by the double antibody method using antiserum NIDDK-anti-oGH-2 (AFP-C0123080). The assay revealed a minimal detectable concentration of $0.2 \mathrm{ng} / \mathrm{ml}$. Plasma IGF-I was assayed by the double antibody method using NIDDKanti-IGF-I rabbit serum (UBK 487). Plasma samples were extracted by mixing with an acid-ethanol solution to dissociate IGF-I from binding proteins before assay ${ }^{7)}$. The assay revealed a minimal detectable concentration of $7 \mathrm{pg} / \mathrm{ml}$.

Calculation and Statistics: The results are shown as the mean and S.E.M. in the text and tables, but only the means are shown in the figures. The mean plasma concentrations of hormones and metabolites were calculated from all the values recorded over $24 \mathrm{~h}$. The molar hormone concentration ratio of insulin to glucagon ( $/ \mathrm{G}$ ratio) was calculated from the mean concentrations of plasma insulin and glucagon. The General Linear Model of the SAS program package (SAS Institute, Cary, NC, USA) was used for statistical analysis. Significant differences in plasma hormone and metabolite concentrations between doses of amino acids within each amino acid used and between amino acids within each dose were determined by single-factor analysis of variance (ANOVA). When the $P$ value was less than 0.05 by ANOVA, Duncan's multiple range test was employed to compare the responses with the control value.

\section{Results}

Effects of Gly administration (Fig. 1): The intraduodenal Gly infusion caused a reduction of feed intake by $14 \%$ of the control at a dose of $14.4 \mathrm{mmol} / \mathrm{kg} / \mathrm{day}$.

Mean plasma concentrations of glucagon and insulin were $28 \pm 7 \mathrm{pg} / \mathrm{m} l$ and $12.4 \pm 1.6 \mu \mathrm{U} / \mathrm{m} l$, respectively, in the control (saline-infused) animals. These values were significantly $(\mathrm{P}<$ 0.01 ) increased by the Gly infusion at all doses for glucagon and at the highest Gly dose for insulin. The maximum mean concentrations of glucagon and insulin were $148 \pm 20 \mathrm{pg} / \mathrm{m} l$ at a dose of $7.2 \mathrm{mmol} / \mathrm{kg} /$ day and $26.2 \pm 3.4 \mu \mathrm{U} /$ $\mathrm{ml}$ at a dose of $14.4 \mathrm{mmol} / \mathrm{kg} / \mathrm{day}$, respectively. The mean plasma $\mathrm{GH}$ concentration was $1.9 \pm$ $0.2 \mathrm{ng} / \mathrm{ml}$ in the control animals, and was only significantly $(\mathrm{P}<0.05)$ increased, to $2.5 \pm 0.4$ $\mathrm{ng} / \mathrm{ml}$, by infusion at the dose of $14.4 \mathrm{mmol} /$ $\mathrm{kg} /$ day. The mean plasma IGF-I concentration was $51.0 \pm 6.8 \mathrm{ng} / \mathrm{m} l$ in the control animals, and was not altered by the infusion. Mean plasma glucose and $\alpha$-amino nitrogen concentrations were $51.9 \pm 2 \mathrm{mg} / 100 \mathrm{ml}$ and $4.8 \pm 0.1$ $\mathrm{mgN} / 100 \mathrm{~m} l$, respectively, in the control animals. These values were significantly $(\mathrm{P}<$ 0.01 ) increased by the Gly infusion at 14.4 $\mathrm{mmol} / \mathrm{kg} /$ day for glucose and at 7.2 and 14.4 $\mathrm{mmol} / \mathrm{kg} /$ day for $\alpha$-amino nitrogen.

Feeding caused complex changes in the concentrations of all hormones and metabolites except for $\alpha$-amino nitrogen which maintained a steady level over $24 \mathrm{~h}$.

Effects of Leu administration (Fig. 2) : Plasma concentrations of glucagon and insulin were significantly $(\mathrm{P}<0.01)$ increased by Leu infusion. The maximum mean concentrations were $109 \pm 9 \mathrm{pg} / \mathrm{m} l$ and $41.8 \pm 2.3 \mu \mathrm{U} / \mathrm{m} l$, respectively, at a dose of $7.2 \mathrm{mmol} / \mathrm{kg} / \mathrm{day}$. In contrast, plasma $\mathrm{GH}$ was significantly $(\mathrm{P}<0.01)$ reduced to $1.2 \pm 0.2 \mathrm{ng} / \mathrm{m} l$ by the infusion at the same dose. The plasma IGF-I concentration 

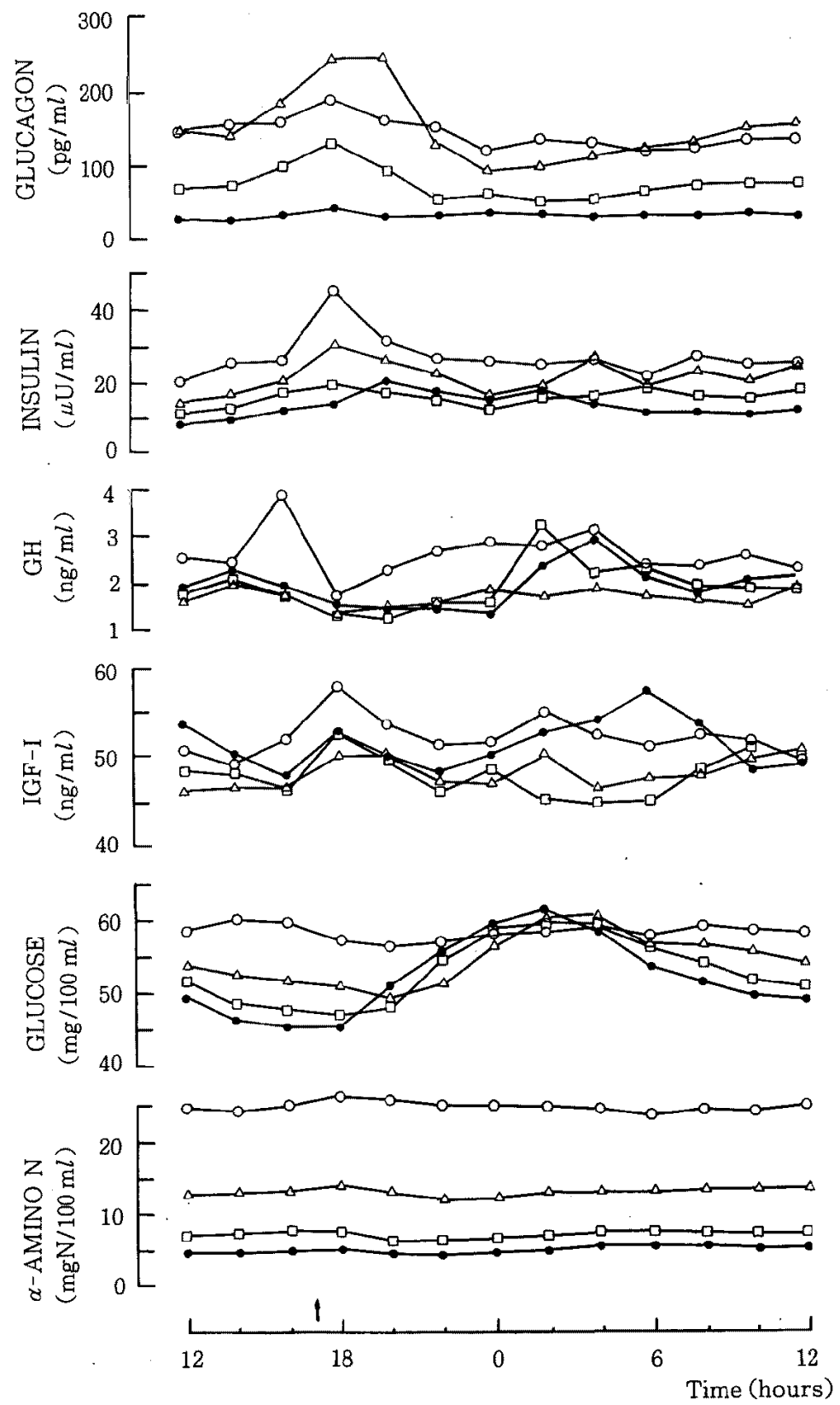

Fig. 1. The effects of intraduodenal continuous infusion of Gly at doses of 0 saline), $3.6(\square), 7.2(\triangle)$, and $14.4(\bigcirc) \mathrm{mmol} / \mathrm{kg} / \mathrm{day}$ on the plasma concentrations of glucagon, insulin, GH, IGF-I, glucose and $\alpha$-amino nitrogen in sheep. All infusions were continued for $96 \mathrm{~h}$. Plasma hormones and metabolites were determined every two hours from $72 \mathrm{~h}$ to $96 \mathrm{~h}$ after starting the infusion. Animals were fed at $17: 00$ hours as indicated by an arrow. The results are represented as the mean of six sheep. 

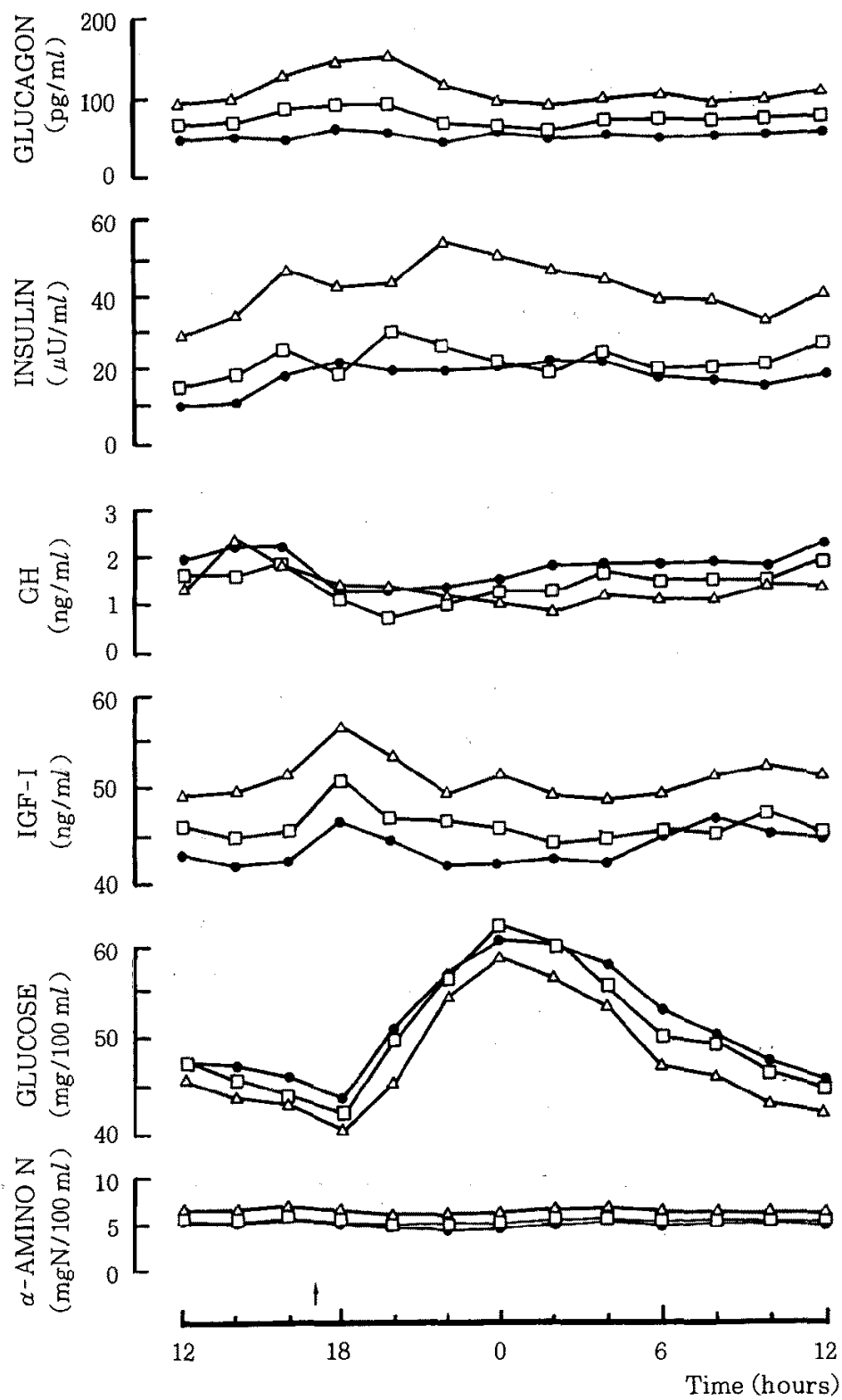

Fig. 2. The effects of intraduodenal continuous infusion of Leu at doses of $O(\bullet), 3.6$ $(\square)$ and $7.2(\triangle) \mathrm{mmol} / \mathrm{kg} /$ day on the plasma concentrations of glucagon, insulin, $G H$, IGF-I, glucose and $\alpha$-amino nitrogen in sheep. Other details are given in the legend to Fig. 1.

was dose-dependently and significantly $(\mathrm{P}<$ 0.01 ) increased from $43.6 \pm 2.1 \mathrm{ng} / \mathrm{m} l$ in the control to $51.0 \pm 3.1 \mathrm{ng} / \mathrm{m} l$ at a dose of 7.2 $\mathrm{mmol} / \mathrm{kg} /$ day.

The plasma glucose concentration was significantly $(P<0.01)$ reduced to $47.5 \pm 1.7 \mathrm{mg} /$ 

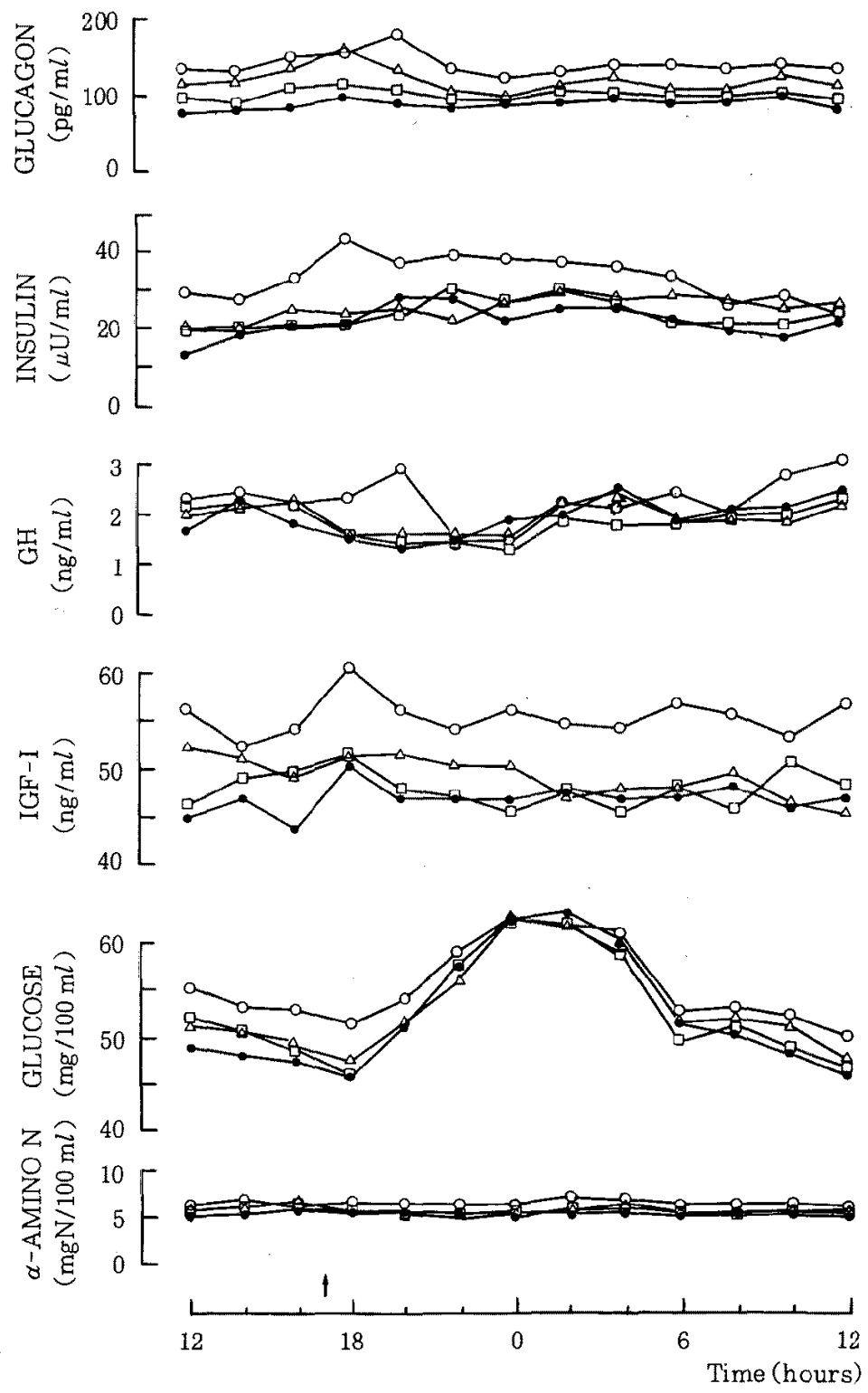

Fig. 3. The effects of intraduodenal continuous infusion of Asp at doses of $0(0), 3.6$ $(\square), 7.2(\triangle)$, and $14.4(\bigcirc) \mathrm{mmol} / \mathrm{kg} /$ day on the plasma concentrations of glucagon, insulin, GH, IGF-I, glucose and $\alpha$-amino nitrogen in sheep. Other details are given in the legend to Fig. 1.

$100 \mathrm{ml}$ at a dose of $7.2 \mathrm{mmol} / \mathrm{kg} /$ day, while that of $\alpha$-amino nitrogen was significantly ( $\mathrm{P}$ $<0.01$ ) increased to the maximum value of 6.1 $\pm 0.1 \mathrm{mgN} / 100 \mathrm{ml}$ at a dose of $7.2 \mathrm{mmol} / \mathrm{kg}$ / day.

Feeding tended to increase the plasma concentrations of glucagon, insulin, IGF-I and glucose, but decreased the GH concentration. 
Table 1. The molar ratio of insulin to glucagon during intraduodenal continuous infusions of Gly, Leu and Asp at doses of 3.6, 7.2 and $14.4 \mathrm{mmol} / \mathrm{kg} / \mathrm{day}$ in sheep

\begin{tabular}{lccc}
\hline \multirow{2}{*}{$\begin{array}{c}\text { Amino } \\
\text { acid }\end{array}$} & \multicolumn{4}{c}{ Infusion rates $(\mathrm{mmol} / \mathrm{kg} /$ day $)$} \\
\cline { 2 - 4 } & 3.6 & 7.2 & 14.4 \\
\hline & $(\%)$ & $(\% 6)$ & $(\% 6)$ \\
Gly & $53.1 \pm 8.3^{\mathrm{a}}$ & $35.5 \pm 9.8^{\mathrm{a}}$ & $40.6 \pm 7.9^{\mathrm{a}}$ \\
Leu & $89.1 \pm 9.1^{\mathrm{b}}$ & $107.0 \pm 9.9^{\mathrm{b}}$ & - \\
Asp & $95.9 \pm 5.8^{\mathrm{b}}$ & $87.7 \pm 8.0^{\mathrm{b}}$ & $95.5 \pm 7.6^{\mathrm{b}}$ \\
\hline
\end{tabular}

Values are given as percentages of the control (saline infusion), and shown as the mean $\pm S . E$. M. of six sheep. Values with different superscripts (a, b) within each infusion rate differ significantly (Duncan's test after ANOVA).

The $\alpha$-amino nitrogen concentration was maintained constant throughout $24 \mathrm{~h}$ as seen with the Gly infusion.

Effects of Asp administration (Fig. 3) : The mean plasma glucagon and insulin concentrations were significantly $(\mathrm{P}<0.01)$ increased by Asp infusion at doses of 7.2 and $14.4 \mathrm{mmol} / \mathrm{kg} /$ day and at $14.4 \mathrm{mmol} / \mathrm{kg} /$ day, respectively. The maximum mean values for glucagon and insulin were $139 \pm 15 \mathrm{pg} / \mathrm{ml}$ and $33.2 \pm 2.6 \mu \mathrm{U} /$ $\mathrm{ml}$, respectively, at a dose of $14.4 \mathrm{mmol} / \mathrm{kg} /$ day. However, the $\mathrm{GH}$ concentration was not influenced by Asp adiministration even at the maximum dose. The IGF-I concentration was significantly $(\mathrm{P}<0.05)$ increased at doses of 7.2 and $14.4 \mathrm{mmol} / \mathrm{kg} /$ day. The maximum mean value was $55.4 \pm 2.6 \mathrm{ng} / \mathrm{ml}$ at a dose of 14.4 $\mathrm{mmol} / \mathrm{kg} /$ day.

The Asp infusion caused a significant increase in glucose $(\mathrm{P}<0.05)$ and $\alpha$-amino nitrogen ( $\mathrm{P}$ $<0.01$ ) concentrations to $55 \pm 1.5 \mathrm{mg} / 100 \mathrm{ml}$ and $6.4 \pm 0.5 \mathrm{mgN} / 100 \mathrm{~m} l$, respectively, at the maximum dose.

Feeding caused a marked increase in the glucose concentration.

$I / G$ ratio (Table 1 ): The mean $I / G$ ratio for the control animal was $9.4 \pm 2.3$. Gly administration significantly $(\mathrm{P}<0.05)$ reduced the $\mathrm{I} / \mathrm{G}$ ratio even at the minimum dose, when compared with Asp or Leu administration.

\section{Discussion}

The present results show that intraduodenal infusions of Gly, Leu and Asp significantly increased the plasma concentration of glucagon, insulin and IGF-I (with the exception of Gly), and that the $\mathrm{I} / \mathrm{G}$ ratio was significantly reduced by the Gly infusion. However, neither Asp nor the other two amino acids was able to increase $\mathrm{GH}$ concentration even at $14.4 \mathrm{mmol} /$ $\mathrm{kg} / \mathrm{day}$.

In our previous paper, we examined the effects of intravenous infusions of seventeen amino acids (each at a dose of $3 \mathrm{mmol} / \mathrm{kg}$ over $30 \mathrm{~min}$ ) on the secretion of glucagon, insulin, $\mathrm{GH}$ and IGF-I in castrated male sheep ${ }^{17)}$. Gly increased both glucagon and insulin secretion, as did serine and alanine. Leu was the most effective amino acid in stimulating insulin secretion without influencing glucagon and GH secretion. Asp was the most effective in increasing GH secretion. However, no amino acid was able to stimulate glucagon secretion alone without also increasing insulin and $\mathrm{GH}$ secretion. IGF-I concentration was not changed by any of the amino acids used. Thus, our interest in the present experiment was to know the effects of continuous intraduodenal infusions of Gly, Leu and Asp lasting for 4 days on the secretion of these hormones in sheep.

The $I / G$ ratio has been used as an index of the relative balance between the actions of glucagon and insulin ${ }^{34)}$. The significant reduction in the $I / G$ ratio induced by Gly infusion suggests that the secretion rate of glucagon exceeds that of insulin, implying a dominant action of glucagon on glycogenolysis and gluconeogenesis. Therefore, when intraduodenally infused at appropriate doses, Gly might be a useful amino acid to enhance catabolism, allowing a large hepatic output of glucose, such as is required in lactation ${ }^{2}$. Administration of a large amount of Gly, however, might not be advisable, since it suppressed feed intake at 


\section{Kuhara, Katoh, Oda, Ohneda and Sasaki}

a dose of $14.4 \mathrm{mmol} / \mathrm{kg} /$ day. On the other hand, Leu and Asp infusion did not change the $\mathrm{I} / \mathrm{G}$ ratio since they enhanced both glucagon and insulin secretion to a similar extent.

Leu appears to be one of most effective branched-chain amino acids in promoting protein anabolism by sparing amino acid catabolism in protein wasting conditions ${ }^{24)}$, as well as being effective in enhancing glucose utilization in peripheral tissues. In our previous paper ${ }^{17)}$, however, intravenous Leu infusion decreased glucagon secretion. This discrepancy might be explained by the suggestion that the enhanced plasma glucagon level induced by an intraduodenal Leu infusion was due to other factors such as hypoglycemia induced by an enhanced insulin secretion. SASAKI et al. ${ }^{30)}$ reported that glucagon secretion induced by intravenous arginine infusion was sustained for a longer period than was insulin secretion.

Asp, when infused intravenously at $3 \mathrm{mmol} /$ $\mathrm{kg}$ over $30 \mathrm{~min}$, caused a marked increase in GH secretion ${ }^{17)}$. This response was not reproduced in the present intraduodenal infusion experiment, where the maximum infusion rate was $14.4 \mathrm{mmol} / \mathrm{kg} /$ day. Although further detailed study is required to account for the discrepancy, one possible explanation is that the $a$-amino nitrogen concentration, which reflects the net absorption of Asp from the intestine into the blood, was not increased to a high enough level to stimulate GH secretion. A rapid increase in plasma amino acid concentrations seems to be necessary to stimulate GH secretion, because the GH secretion induced by intravenous Arg administration at a low infusion rate over a long period was reported to be smaller than that induced by a high rate of infusion over a short period even when the same total dose was given ${ }^{13)}$. It is known that in the ovine small intestine the Gly transport system is not saturated, although it shows a lower affinity and lower transport rate than for other amino acids ${ }^{15}$. Thus, the large increase in plasma $a$-amino nitrogen concentra- tion during Gly infusion in the present study might be due to the large capacity of Gly transport systems. On the other hand, Asp infused into the duodenum might be converted to other metabolites by the intestinal epithelium or might be consumed by bacteria in the small intestine before being absorbed, resulting in a small increase in $\alpha$-amino nitrogen concentration and consequently a very limited increase in $\mathrm{GH}$ secretion.

In the present study, the plasma IGF-I level was increased by Leu and Asp infusions, but seemed to be independent of plasma GH levels. The plasma IGF-I level in humans is known to be increased more rapidly when essential amino acids are added to a nitrogen deficient diet than when non-essential amino acids are used ${ }^{6)}$. Dietary protein might be the primary nutritional determinant of basal IGF-I levels with undernutrition also attenuating the IGF-I response to $\mathrm{GH}$ in cattle ${ }^{10)}$. IGF-I release was stimulated by insulin administration ${ }^{16)}$, but IGF-I was a potent inhibitor of insulin secretion itself ${ }^{18)}$. Furthermore, IGF-I exerted a suppressive action on GRF-induced GH secretion by a negative feed-back system in ovine pituitary cells in vitro ${ }^{31)}$. These findings indicate the complex relationships existing between $\mathrm{GH}$ and IGF-I.

Feeding behavior is known to alter the status of hormones and metabolites in plasma. The plasma concentrations of glucagon ${ }^{21)}$ and insu$\operatorname{lin}^{13}$ were slightly increased, but glucose-induced insulin secretion was decreased ${ }^{29)}$, after feeding in sheep. Furthermore, both plasma GH concentration and GRF-induced GH secretion were reduced after feeding in sheep ${ }^{1,33)}$. The enhanced release of GH shown at the maximum dose of Gly infusion (Fig. 1) might result from the suppression of feed intake induced by the infusion, because it has been reported that the removal of food for $10 \mathrm{~h}$ promptly increased both the size and frequency of $\mathrm{GH}$ secretion in sheep ${ }^{9)}$, and that arginineinduced $\mathrm{GH}$ secretion was greater in fasted 
than in fed heifers ${ }^{20)}$. When Asp was infused into the duodenum at $14.4 \mathrm{mmol} / \mathrm{kg} / \mathrm{day}$ the suppression of GH secretion after feeding tended to be overcome. As pointed out earlier, the intravenous infusion of Asp was the most effective amino acid in stimulating GH secretion. Therefore, the slight and significant increase in the plasma $\alpha$-amino nitrogen, Asp may relate to the attenuation of the reduced GH secretion after feeding during the highest Asp infusion. Feeding is known to cause a transient decrease followed by a sustained increase in the glucose concentration, while it caused a transient increase in the $\alpha$-amino nitrogen concentration in sheep ${ }^{1,21,28)}$.

In lactating cattle, OLDHAM et $a l^{26)}$ reported that an increased supplementation of amino acids into the intestine by feeding protein supplements enhanced the blood GH concentration about two-fold, but did not influence milk production. In contrast, plasma GH levels were elevated five- to ten-fold when milk yield was increased by GH injection ${ }^{8)}$. Therefore, it may require a large increase in the plasma GH level to enhance milk production by a galactopoietic response to GH when attempts are made to preferentially increase plasma $\mathrm{GH}$ secretion by feeding dietary protein and/or amino acids.

In conclusion, intraduodenal infusions of amino acids (Gly, Leu, Asp) significantly increased the plasma concentrations of glucagon; insulin and IGF-I (with the exception of Gly), and the $I / G$ ratio was significantly reduced by the Gly infusion. The present results suggest that it would be possible to modify plasma concentrations of glucagon, insulin and IGF-I by intraduodenal infusion of some amino acids.

\section{Acknowledgment}

The authors gratefully acknowledge Dr. T.E.C. WEEKES, University of Newcastle, for comments on the manuscript, and the National Hormone and Pituitary Program (NIDDK) for giving antiserum to $\mathrm{GH}$ and IGF-I. This study was, in part, supported by a Grant-in-Aid for Scientific Research (B) from the Ministry of Education, Science, and Culture of Japan (No. 62480077).

\section{References}

1) BASSETT, J.M., Diurnal patterns of plasma insulin, growth hormone, corticosteroid and metabolite concentrations in fed and fasted sheep. Aust. J. Biol. Sci., 27 : 167181. 1974.

2) Bergman, E.N. and D.E. Hogue, Glucose turnover and oxidation rates in lactating sheep. Am. J. Physiol., 213: 1378-1384. 1967.

3) Brockman, R.P. and E.N. Bergman, Effect of glucagon on plasma alanine and glutamine metabolism and hepatic gluconeogenesis in sheep. Am. J. Physiol., 228: 1627-1633. 1975.

4) Chew, B.P., J.R. Eisenman and T.S. Tanaka, Arginine infusion stimulates prolactin, growth hormone, insulin, and subsequent lactation in pregnant dairy cows. J. Dairy Sci., 67 : 2507-2518. 1984.

5) Clark, J.H. Lactational responses to postruminal administration of proteins and amino acids. J. Dairy Sci., 58: 11781197. 1975.

6) ClemMons, D.R., M.M. SEEK, and L.E. UNDERWOOD, Supplemental essential amino acids augment the somatomedin-C/insulin-like growth factor I response to refeeding after fasting. Metabolism, 34: 391395. 1985.

7) Daughaday, W.H., I.K. Mariz, and S.L. BLETHEN, Inhibition of access of bound somatomedin to membrane receptor and immunobinding sites: a comparison of radioreceptor and radioimmunoassay of somatomedin in native and acid-ethanolextracted serum. J, Clin. Endocrinol. \& Metab., 51 : 781-788. 1980.

8) Davis, S.R., P.D. Gluckman, I.C. Hart and H.V. Henderson, Effects of injecting growth hormone or thyroxine on milk production and blood plasma concentrations of insulin-like growth factors $I$ and II in dairy cows. J. Endocrinol., 114: 17-24. 1987.

9) Driver, P.M. and J.M. Forbes, Episodic growth hormone secretion in sheep in rela- 
tion to time of feeding, spontaneous meals and short term fasting. J. Physiol. (Lond), 317: 413-424. 1981.

10) Elsasser, T.H., T.S. Rumsey and A.C. Hammond, Influence of diet on basal and growth hormone-stimulated plasma concentrations of IGF-I in beef cattle. J. Anim. Sci., 67 : 128-141, 1989.

11) Gluckman, P.D., B.H. Breier and S.R. Davis, Physiology of the somatotropic axis with particular reference to the ruminant. J. Dairy Sci., 70: 442-466. 1987.

12) Goldberg, A.L., M. Tischler, G. DeMartiNo and G. GRIFFING, Hormonal regulation of protein degradation and synthesis in skeletal muscle. Fed. Proc., 39: 31-36. 1980.

13) Hertelendy, F., K. Takahashi, L.J. MACHLIN and D.M. KIPNIS, Growth hormone and insulin secretory responses to arginine in the sheep, pig, and cow. Gen. Comp. Endocrinol,, 14: 72-77. 1970.

14) Huggets, A.G. and D.A. Nixon, Enzymic determination of blood glucose. Biochem. J., $66: 12.1957$.

15) Johns, J.T. and W.G. BERGEN, Studies on amino acid uptake by ovine small intestine. J. Nutr., 103 : 1581-1586. 1973.

16) Kogawa, M., K. Takano, K. Asakawa, N. Hizuka, T. Tsushima and K. Shizume, Insulin stimulation of somatomedin production in monolayer cultures of rat hepatocytes. Acta Endocrinol., 103: 385390. 1983.

17) Kuhara, T., S. IKEDA, A. OHneda and Y. SASAKI, Effects of intravenous infusion of seventeen amino acids on the secretion of $\mathrm{GH}$, glucagon and insulin in sheep. Am. J. Physiol., 260 : E21-E26. 1991.

18) LEAHY, J.L. and K.M. VANDEKERHOVE, Insulin-like growth factor-I at physiological concentrations is a potent inhibitor of insulin secretion. Endocrinology, 126 : 1593-1598. 1990.

19) LEe, Y.P. and T. Takahashi, An improved colorimetric determination of amino acids with the use of ninhydrin. Anal. Biochem., $14: 71-77.1966$.

20) McAtee, J.W. and A. Trenkle, Effect of feeding, fasting, and infusion of energy substrates on plasma growth hormone levels in cattle. J. Anim. Sci., 33: 612-616. 1971.
21) Mineo, H., T. Oyamada, T. Yasuda, M. AkiYama, S. Kato and J. UshiJima, Effect of feeding frequency on plasma glucose, insulin and glucagon concentrations in sheep. Jpn. J. Zootech. Sci., 61: 411-416. 1990.

22) Ohneda, A., S. IshiI, K. HoRigome and S. YAMAGATA, Glucagon response to arginine after treatment of diabetes mellitus. Diabetes, $24: 811-819.1975$.

23) Ohneda, A., K. Watanabe, M. Wakimatsu and M. Fujino, Production of a specific antiserum by synthetic $\mathrm{C}$-terminal fragment of glucagon. Horm. Metab. Res., 11 : 463-468. 1979.

24) Okada, A., S. Mori, M.M. Totsuka. K. Okamoto, S. Usui, H. Fujita, T. Itakura and H. Mrzote, Branched-chain amino acids metabolic support in surgical patients: a randomized controlled trial in patients with subtotal or total gastrectomy in 16 Japanese institutions. J. Parenter. Enteral Nutr., 12 : 332-337. 1988.

25) Oldham, J.D., I.C. HaRT and J.A. Bines, Effect of abomasal infusions of casein, arginine, methionine or phenylalanine on growth hormone, insulin, prolactin, thyroxine and some metabolites in blood from lactating goats. Proc. Nutr. Soc., 37 : 9A. 1978.

26) Oldham, J.D., I.C. HaRT and J.A. Bines, Formaldehyde-treated proteins for dairy cows-effects on blood hormone concentrations. Brit. J. Nutr., 48 : 543-547. 1982.

27) SASAkI, $Y$. and $H$. TAKAHASHr, Insulin secretion in sheep exposed to cold. J. Physiol. (Lond), 306 : 323-335. 1980.

28) SASAKI, Y., H. HrRatSUKa and M. Ishida, Effect of cold exposure on insulin response to feeding in sheep. Can. J. Anim. Sci., 64 (Supplement) : 269-270. 1984.

29) Sasaki, Y., H. Takahashi, H. Aso, K. Hikosaka, A. Hagino and S. ODA, Insulin response to glucose and glucose tolerance following feeding in sheep. Brit. J. Nutr, 52 : 351-358. 1984.

30) Sasaki, Y., H. Takahashi, H. Aso, A. OHNEDA and T.E.C. WEEKES, Effects of cold exposure on insulin and glucagon secretion in sheep. Endocrinology, 111: 20702076. 1982.

31) Silverman, B.L., M. Bettendorf, S.L. Kaplan, M.M. Grumbach and W.L. Miller, 


\title{
Hormone Responses to Amino Acids
}

Regulation of growth hormone $(\mathrm{GH})$ secretion by GH-releasing factor, somatostatin, and insulin-like growth factor $I$ in ovine fatal and neonatal pituitary cells in vitro. Endocrinology, 124: 84-89. 1989.

32) SPITSBERG, V.L., A selective extraction of growth hormone from bovine pituitary gland and its further purification and crystallization. Anal. Biochem., 160 : 489-
495. 1987.

33) Trenkle, A., Influence of feeding on growth hormone secretion and response to growth hormone-releasing factor in sheep. J. Nutr., 119 : 61-65. 1989.

34) UNGER, R.H., Glucagon and the insulin : glucagon ratio in diabetes and other catabolic illnesses. Diabetes, 20 : 834-838. 1971.

\section{ヒツジの代謝性ホルモン分泌に及ぼす 十二指腸内アミノ酸投与の影響}

\author{
久原徹哉 ${ }^{*}$-加藤和雄・小田伸一・大根田 昭 ${ }^{* *}$ ・佐々木康之 \\ 東北大学農学部，仙台市青葉区 981 \\ **東北大学保健管理センター, 仙台市青葉区 981
}

反鴐家畜へのアミ，酸投与は、各種の代謝性ホルモンの分泌を介して生産性に寄与すると考えられる. 本研究では，グリシン，ロイシン，アスパラギン酸をそれぞれ4 日問 (96 時間), 十二指腸内に連続投 与した場合の血浆ホルモン濃度について検討した。予め麻酷下に十二指腸カテーテルおよび頝動脈ルー プを装着した去勢雄成ヒッシ 6 頭を供試し, 各アミノ酸連続投与 4 日目に, 頝動脈より経時的に採血し, $\mathrm{GH}$, インスリン，グルカゴン，IGF-I の血将濃度を測定した，アミノ酸の注入量は，0，3.6，7.2， $14.4 \mathrm{mmol} / \mathrm{kg} / \mathrm{day}$ とした．グリシン投与により，血采インスリンおよびグルカゴン濃度は，投与量 に依存して上昇した。最も高い1日平均血羁インスリン濃度は，グリシン $14.4 \mathrm{mmol} / \mathrm{kg} / \mathrm{day}$ 注入 時の $26.2 \pm 3.4 \mu \mathrm{U} / \mathrm{m} l$ (対照 $12.4 \pm 1.6 \mu \mathrm{U} / \mathrm{m} l$ ) であり，血将グルカゴン蕽度は, グリシン 7.2 $\mathrm{mmol} / \mathrm{kg} / \mathrm{day}$ 注入時の $148 \pm 20 \mathrm{pg} / \mathrm{ml}$ (対照 $27.9 \pm 7.1 \mathrm{pg} / \mathrm{ml}$ ) が最大であった。また, グリシン 注入により I/G 比（インスリン/グルカゴン：モル比）は、他のアミノ酸注入に比べ, 有意に低下した。 グリシンは, 血浆 GH, IGF-I 濃度に明かな変動を与えなかった。，一方，ロイシン，アスパラギン酸 の投与により，血浆インスリン，グルカゴン，IGF-I 濃度が各々有意に上昇したが，血䍝 GH 濃度に はほとんど影響を与えなかった，以上の結果から，特定アミノ酸を十二指腸に注入することで，ヒッジ の血䍝インスリン、グルカゴンおよび IGF-I 濃度を調節できることが示唆された。

日畜会報, $63(11) ： 1123-1133,1992$

*現所属：森永乳業生物科学研究所, 座間市 228 